\title{
Proclus on the order of philosophy of nature
}

\author{
Marije Martijn
}

Received: 26 February 2007 / Accepted: 20 March 2008 / Published online: 6 November 2008

(C) The Author(s) 2008. This article is published with open access at Springerlink.com

\begin{abstract}
In this paper I show that Proclus is an adherent of the Classical Model of Science as set out elsewhere in this issue (de Jong and Betti 2008), and that he adjusts certain conditions of the Model to his Neoplatonic epistemology and metaphysics. In order to show this, I develop a case study concerning philosophy of nature, which, despite its unstable subject matter, Proclus considers to be a science. To give this science a firm foundation Proclus distills from Plato's Timaeus the basic concepts Being and Becoming and a number of basic propositions, among others the quasi-definitions of the basic concepts. He subsequently explains the use of these quasi-definitions, that are actually epistemic guides, in such a way that he obtains a connection between a rational and an empirical approach to the natural world. A crucial task in establishing the connection is performed by the faculty of doxa and by geometrical conversion. The result is that Proclus secures a universal, necessary and known foundation for all of philosophy of nature.
\end{abstract}

Keywords Proclus · Philosophy of nature · Science

\section{Introduction}

In his seminal article 'The ancient axiomatic theory', Scholz states that Aristotle, in producing a first general description of exact science in the Posterior analytics did such a marvellous job that "after his time, we may say, antiquity added nothing new to it". This judgment, he continues, echoes one passed by Proclus (411-485 AD), "the last

M. Martijn (殴

Faculteit der Wijsbegeerte, Vrije Universiteit Amsterdam,

De Boelelaan 1105, 1081 HV Amsterdam, The Netherlands

e-mail: M.Martijn@ph.vu.nl 
competent interpreter among the ancients". ${ }^{1}$ Unfortunately, Scholz does not refer to any particular passage in Proclus' works. Regardless, however, of what he had in mind, let us juxtapose his echo with the following words of the Neoplatonic philosopher:

the analytic method of the Peripatos, and its chief component, demonstration, is easy to apprehend and crystal-clear to everyone who is not entirely dizzy, and groggy from the water from the river Lethe. (In Crat. 2.10-2.13) ${ }^{2}$

Expressions such as 'easy to apprehend' and 'crystal-clear' are appreciative enough. But the addition of 'dizziness' and 'water from the river Lethe', the source of oblivion from which the souls drink before their incarnation, ${ }^{3}$ reveals that instead, Proclus is here criticising Aristotle's method of demonstration as set out in the Analytics by putting it down as a method for simple minds: it is stripped of content, ${ }^{4}$ and anyone can understand it. This impression is reinforced by the context. Proclus is comparing the logic or dialectic of Aristotle to that of Plato, and the latter is considered superior by far, since it ultimately studies the highest principle, the Good, and is suitable only for those with a purified and properly trained faculty of reason (In Crat. 1.12-2.1).

Proclus' critical stance towards Aristotle's Analytics can in part be explained as rhetoric. Proclus, who writes eight centuries after Aristotle's Posterior analytics, is a Platonist who is convinced that Aristotle and Plato could be harmonised, because Aristotle was a Platonist, ${ }^{5}$ and that, in case of disagreement, Aristotle should be the one to be criticised. If the methods of Aristotle and Plato were to be compared at all, Plato's would always be considered to contain everything we find in Aristotle, except for the mistakes. 6

In light of the theme of this issue, this paper will stick to the method for the simple minds, and study Proclus' views of scientific method, which he himself dubs 'geometrical methods'. Since O'Meara's important monograph Pythagoras Revived it is commonly accepted that the attribute 'geometrical' in this context has little to do with mathematization in the modern sense, and that the role of geometry is limited to providing a paradigm (O'Meara 1989, p. 182).

What has not been adequately realised is that to a great extent that paradigm follows the Classical Model of Science as described in the introduction of this issue (see de Jong and Betti 2008), and that likewise Proclus' 'geometrical method' follows that Model as found in the first systematic account of it: Aristotle's organon (plus the

\footnotetext{
1 Scholz (1930/1975, p. 50).

2 In fact, Scholz may have had these very words in mind. I was unable to find any other reference to Aristotle's scientific theory that even came close to Scholz' words.

3 "To suffer from dizziness or vertigo" is used by Plato (Theaet. 155C, Laws 633B, cf. ib. 892E and Soph. 264C) to indicate a situation of complete confusion caused by the complexity of an argument.

4 Cf. ibid. 1.11. Cf. Plot. Enn. I.3.5.8-I.3.13.

5 This position may sound strange to our ears that are so accustomed to the opposition of Plato to Aristotle, but in late antiquity it was well established. Moreover, recently it has gained more popularity. Cf. Gerson (2005).

6 Cf. Alcinous who, as Dillon (1993, p. xvi) has shown, manages to incorporate a great deal of Aristotelian (and Stoic) doctrine into this handbook, without identifying it as such, and while remaining Platonic in essence.
} 
ensuing commentary tradition), ${ }^{7}$ and its first strict application: Euclid's Elements. ${ }^{8}$ A thorough analysis of the influence of those works on Proclus' ideal of science has yet to be undertaken. ${ }^{9}$

In this paper, I will discuss Proclus' adherence to the Classical Model of Science. After a brief general survey of the Model (Sect. 2) I present a case study, concerning philosophy of nature (physiologia). The main thesis of this paper is that Proclus adopts the Model, adapts it to his Neoplatonic metaphysics and uses it to show that philosophy of nature is a science. This will be illustrated by focusing on the role that three of the conditions of the Model play in Proclus' physiologia: condition 2a, that in a science $S$ there is a number of fundamental concepts, condition 5, that all propositions of $S$ are necessary in some sense, and condition 7, that the concepts and propositions are adequately known. ${ }^{10}$

\section{Proclus and the Model}

Although Proclus, like so many other adherents of (versions of) the Model (see de Jong and Betti 2008), did not write a separate theory of science, detailed information on the theory he uses can be gathered from applications and explicit discussions of elements of the Model.

First of all, some of his systematic works contain clear applications of components of the Model, as they are presented as demonstrations more geometrico. The best known and most influential work of Proclus generally taken as an example of such an application is his Elements of Theology, an exposition of the basic principles of Neoplatonic metaphysics. As has been pointed out by several scholars, however, despite their name the Elements of Theology are essentially different from Euclid's Elements. The former are presented as a deduction from the first proposition 'Every plurality partakes in some way in unity', followed by a demonstration and ensuing propositions, but the demonstrations are not preceded by definitions, postulates and axioms. ${ }^{11}$ A work that is closer to Euclid's Elements in this sense is the Elements of Physics, which is based on a selection of passages from Aristotle's Physics, concerning motion and the unmoved mover, presented as a sequence of propositions plus demonstrations, this time preceded by definitions (cf. Nikulin 2003).

The disadvantage of the systematic works for our purposes, is that they are pure presentations of scientific knowledge, which do not also ascend to a meta-level and theorize about the principles underlying that presentation.

\footnotetext{
7 Hathaway (1982, p. 124) names only the Pythagoreans, Zeno, Plato, and Euclid as sources for Proclus' ideas of scientific method.

8 This is not to say, of course, that Aristotle's description or Euclid's practice of scientific knowledge correspond exactly to the Model, or that the Model is not to be found in Stoic or Platonic context.

9 The same goes for other Platonic philosophers, whose Aristotelian heritage has only recently become the subject of closer study. For Plotinus see e.g. de Haas (2001); Chiaradonna (2002), Longo (2006, esp. II); for Syrianus see Longo (2005).

10 Space does not allow me to go into Proclus' use of the other conditions of the Model.

11 For more arguments against the thesis that Proclus' Elements of Theology are the first Western attempt at an axiomatization of metaphysics, see O'Meara (1989, $196 \mathrm{ff})$, O'Meara (2000, pp. 285-286), Hathaway (1982, pp. 123-124), Lowry (1980), Lohr (1986, pp. 59-60).
} 
The second source of information on Proclus' adherence to the Model can be found in remarks on methodology and prerequisites of scientific knowledge, which are present to some degree in each of his commentaries, but especially in the commentary on the first book of Euclid's Elements. The double prologue of this commentary is devoted to a discussion of the nature of mathematics and geometry respectively, and in part amounts to an explicit formulation of an ideal of (those) science(s). Of the commentaries on Platonic dialogues, that on the Timaeus is the most valuable for our purposes. Here, as in the other commentaries, we are offered a combination of discussions and applications of components of his scientific method. But what is more, Proclus' views on philosophy of nature form an interesting case-study regarding his version of the Model, due to the strained relation between nature and science in Platonism.

\section{The case of philosophy of nature}

Today, the natural sciences are considered the paradigm of science. For Plato, however, and all Platonic philosophers after him (i.e. any later philosopher adhering to some version of his views), the object of true scientific knowledge was not the ever-changing natural world, but rather the eternal world of transcendent Forms. The most famous description of the unreliability of studies of the natural world is without doubt the one we find in Plato's own cosmological account (Timaeus 29C4-29C8).

Proclus, nonetheless, delivers a Commentary on the Timaeus that defends the possibility of scientific knowledge of the natural world, ${ }^{12}$ while at the same time maintaining a thoroughly Platonic position on the essential instability of that world. And it is exactly this combination of a subject matter that defies certainty on the one hand and a defence of the possibility of scientific knowledge of that subject matter on the other, that provides us with a clear view of what constitutes a science according to Proclus, and hence of his version of the Model.

Proclus finds the material on which he bases his defence in the proømium of Plato's Timaeus, i.e. the introduction Timaeus gives to his exposition on the universe. ${ }^{13}$ It is a description of the starting points, i.e. the primitive concepts and propositions of all of physiologia. Before we can move on to the details of the defence, a summary of those starting points, following Proclus' division of them, is in order.

\subsection{Outline of the proœmium of the Timaeus}

\section{Being and Becoming ${ }^{14}$}

The first starting point is the distinction between the transcendent realm of Forms which is known through understanding combined with a rational account (Being),

\footnotetext{
12 See also Festugière (1963), O'Meara (1989, esp. 179 ff) and Lernould (2001).

13 Plato Tim. 27C1-29D3, with Proclus' commentary at In Tim. I.204-I.354. For the sake of clarity: in the following I will discuss Proclus' reading of Plato's Timaeus (Tim.), as presented in his Commentary on the Timaeus (In Tim.).

14 I use capitals for 'Being' and 'Becoming' whenever they are used as nominalizations referring to realms of Platonic reality, rather than the present continuous of to be and to become respectively.
} 
and the realm of generation which is grasped by belief (doxa $)^{15}$ combined with sense perception (Becoming).

\section{The efficient cause of Becoming}

The second starting point states that 'anything Becoming has a(n efficient) cause'. In the case of the universe as a whole, this cause is referred to as the 'demiurge'.

\section{The paradigmatic cause and the copy}

The third starting point assumes that every efficient cause creates with the aid of a paradigm that is Being or Becoming, and states that the quality of the paradigm determines the quality of the copy.

\section{Transition to the subject matter, the universe}

The three starting points are subsequently applied to the main subject of the exposition, the universe, in the following manner:

1.* the universe is Becoming, because it is accessible to sense perception

2.* therefore, the universe has an efficient cause, its 'father' or 'maker'

3.* this maker created the universe as the copy of a paradigm that is eternal Being ${ }^{16}$

And finally,

\section{The likely story}

The proœmium ends with the well-known principle of the likely story, which states the dependence of the nature of a text on that of its subject matter. As a text about a copy (according to $3 *$ ), which has a likeness to its model, Timaeus' story will be a 'likeness', a likely story. ${ }^{17}$

It has been suggested by modern commentators, albeit with some reservations, that in this prooemium we find the application of the method Plato describes in the Phaedo, i.e. a foreshadowing of an (hypothetico-)deductive method. ${ }^{18}$ One could say

\footnotetext{
15 On this translation of doxa see footnote 57.

16 Where 'being created' is understood in the sense of 'being ontologically dependent on', in a non-temporal sense, and not as creatio ex nihilo.

17 The two pages in which Plato formulates this introduction to his cosmology have raised a great number of issues from the moment they were written. See Martijn (2006, Sect. II) and Martijn (2008, Ch. V) for overviews.

18 Runia (1997, pp. 111-112), Vlastos (1975, pp. 28-29), cf. Mourelatos (1991). Vlastos is sceptical: "The bare logical schema of hypothetico-deductive science can, no doubt, be found in the Timaeus" (1975, p. 26), but "modern accounts that claim to find in the Timaeus a prefiguring of our hypothetico-deductive conception of science fail to hear the chuckles of play and irony in Timaeus' voice" (1975, p. 29).
} 
that Proclus was the first to make a similar suggestion, and far more resolutely than modern commentators. ${ }^{19}$

\subsection{Physiologia a science?}

In his explanation of the 'likely story', the dismissal of physiologia as not presenting hard facts but probabilities (\#V in the outline), Proclus reports that physiologia cannot be a science for Plato due to the narrow definition of science adopted in the Timaeus. As in the case of most ancient writers, Plato's identification of a certain discipline as scientific is not a rigid designation. ${ }^{20}$ As Proclus points out, his great predecessor wields different (cumulative) criteria, according to which a discipline qualifies as a science:

Plato sometimes defines science (epistêmê) as 'providing causes', sometimes as 'the subject matter also having an entirely permanent essence, on top of giving account of the causes', sometimes as 'the principles not being hypotheses' ${ }^{21}$

By the first definition, and only by that one, would physiologia be a science. It could never be an unhypothetical science, since this is a prerogative reserved for theological dialectic; ${ }^{22}$ it can also never be a purely dianoetic science (as are the mathematical sciences), since the subject matter of physiologia does not have a permanent essence. The only sense in which philosophy of nature can be a science is by providing the causes of natural phenomena. By adopting the narrower second definition, Plato reduces physiologia to a 'likely story' (In Tim I.350.12-I.350.20): the mere nature of the world of sense perception, i.e. Becoming, prevents its constituent propositions to be strictly universal, necessary (in the ordo essendi or cognoscendi), and known (to be true). ${ }^{23}$ The level of cognition that can be attained with regard to nature, according to the first starting point of the proœmium, is (true) belief, doxa.

19 Although for Proclus there is an important difference between the Timaeus, a didactic text, and the Phaedo, which describes the method of discovery. Cf. In Parm. $655.16 \mathrm{ff}$.

20 On Plato's different divisions of the sciences and forms of cognition Phil. 55c-59c; Statesman 258e260b; Rep. 537c and Mourelatos (1991). Like Plato, Proclus does not adhere to one hierarchy of the sciences. Instead, he presents several divisions, which differ mainly because of their different focus, since they are tailor-made for particular contexts. The conditions of the Classical Model of Science are always presupposed, however. See (1) In Eucl. 30.10-32.20, inspired on a combination of Plato's Divided Line (Rep. VI 509D ff) and Aristotle's APo; (2) De Prov. 27-32, inspired on Plato; (3) ibid. 31.10-31.12, Theol. Plat. and In Eucl. 10.15-11.9, based on the principle that 'like is known by like'. That the hierarchies are context-related does not mean that Proclus would deny the validity of any of them outside that context. For an attempt to turn them into a unified Proclian hierarchy of all sciences and forms of cognition, see Lernould (1987), cf. Siorvanes (1996, $141 \mathrm{ff})$.

21 In Tim. I.350.8-I.350.12. These three criteria can be compared to the Postulate of Grounded Knowledge, the Necessity Postulate, and the Postulate of Knowledge (see de Jong and Betti 2008), which goes to showassuming, as I do, that Proclus is right here-that the Classical Model in at least some respects predates Aristotle.

22 On the position that Proclus' philosophy of nature does have unhypothetical starting points, see Lernould (2001).

23 As required by the Model, see de Jong and Betti (2008). 
Fortunately, the judgment of physiologia sketched above is Proclus' interpretation of Plato's stance. Proclus' own verdict is far less harsh: he follows Plato in adopting the second definition, yet without thereby disqualifying physiologia as a science.

How then does Proclus guarantee a scientific status for physiologia? First of all, the proœmium of the Timaeus is analysed in such a way as to summon a scientific environment for physiologia by fulfilling the Postulate of Order (de Jong and Betti 2008). The Postulate of Order says that a science consists of certain primitive concepts, from which all other concepts are definable, and fundamental propositions, from with the other propositions follow. Proclus distinguishes two basic concepts, four basic propositions, and demonstrations based on these starting points. In doing so, he claims necessity for the propositions of physiologia. ${ }^{24}$ Secondly, in his explanation of the first of those demonstrations Proclus provides us with a short but definitive argument in favour of accepting physiologia as a science, by ensuring knowability and universality of the propositions.

\section{Basic concepts and propositions}

Like any other discipline, physiologia has certain proper starting points that distinguish it from other disciplines and that are its foundation:

Like a geometer, Plato seems to take up definitions before the demonstrations and hypotheses, through which he will make the demonstrations, and to lay down beforehand the foundations of the entire philosophy of nature: for just as there are different starting points of poetry, of medicine, of arithmetic and of mechanics, so too are there certain starting points of the entire philosophy of nature. ...From these everything that follows proceeds. ${ }^{25}$

Even before these definitions and hypotheses, however, the enterprise of philosophy of nature has its unique starting point in a question: whether the universe has come into being (In Tim. I.219.21-I.219.22). Everything else, according to Proclus, follows from that. That is, because of the reply to this question we will know the essence of the universe, which in turn will have certain consequences. ${ }^{26}$ In order to answer this first problema concerning the universe, we have to understand what it is (not) to have come into being, in other words, define Being and Becoming (In Tim. I.235.32-I.236.13).

Thus the determination of the essence (eidos) of the universe (276.19-276.21; 226.28) will be reached through an analysis of the two relevant realms of reality, Being and Becoming. As Plato says,

well then, in my opinion first the following division should be made (diaereteon tade): what is that which always is, but does not have generation, and what is that which is (always) becoming, but never really is? (Tim. 27D6-28A1)

\footnotetext{
${ }^{24}$ He presupposes that necessity of the propositions is guaranteed by their following deductively from the basic propositions that are themselves necessary. Cf. In Tim. I.337.3-I.337.17. Of the four propositions, only two will be discussed in the following.

25 In Tim. I.236.13 ff. Note that Proclus includes both epistêmai and technai.

${ }^{26}$ In Tim. I.219.2-I.219.31, cf. In Tim. I.275-I.276.7.
} 
Inspired by Plato's choice of words and by a desire to encounter all dialectical methods in the proœmium, and in the proper order, ${ }^{27}$ in first instance Proclus sees applications of the methods of division (diairesis) and definition in the discussion of these two realms. ${ }^{28}$

\subsection{The division}

Proclus' scholastic discussion of all possible kinds of division to determine which one applies, however, ends in discarding the possibility that we are dealing with a division altogether (In Tim. I.224.17-I.227.3). A real Platonic diairesis, of any type, is a division of things (entities, qualities etc.) that are on equal level within a taxonomy, be it ontological, semantic or otherwise. Since Being and Becoming are essentially different, in many respects each other's contraries, but moreover not on the same ontological level (as Being is prior to Becoming), a division of these two is impossible. ${ }^{29}$ Moreover, there is no genus above Being, which makes it altogether impossible to give a division in which Being figures. ${ }^{30}$ According to Proclus, instead of a division Plato is only making a 'delimiting distinction' (diakrisis aphoristikê): $:^{31}$

The division is not of one thing, but the current study needs the distinction of these two genera before everything else, in order that the exposition proceeds as from geometrical hypotheses to the examination of the consequences and discovers the nature and the efficient and paradigmatic causes of everything. (In Tim. I.226.22-I.227.3) (2 $^{32}$

According to Proclus, one of the tasks of a good scientist is to distinguish between different genera and to choose the proper demonstration accordingly, i.e. the one that uses the starting points fitting to the subject matter and that has the appropriate epistemological status and degree of certainty. ${ }^{33}$ In physiologia the distinction of the

\footnotetext{
27 Of the dialectical methods involved in the synthetic, downward path, i.e. division, definition, and demonstration, division is considered the most august, and is to be applied first because it provides the principles of definition, which in turn is the basis of demonstration. Cf. In Parm. 982.11-982.15, Theol.Plat. I.9.40.10-I.9.40.12, In Parm. 980.33 ff, 981.3, 24, In Eucl. 206.13. Cf. Beierwaltes (1979, p. 248).

28 See Phaedrus (265C-266D), Sophist (216A-232A) and Statesman (258B-268D; 274E-end).

29 Proclus sees a parallel with the distinction of three highest genera in Plato's Philebus (23C-D).

30 Cf. footnote 49. The fascinating question whether the same holds for Becoming, or whether e.g. it is instead a species of Being, is not answered by Proclus, and is probably not easily resolved. It will not be treated here.

31 In Tim. I.225.24-I.226.2. Cf. Proclus' almost identical comments on Plato Parm. 135B3 (In Parm. 976.26-976.38).

32 Cf. Plotinus, who explicitly rejects Severus' insertion of a genus 'something' above Being and Becoming as ridiculous. Plotinus moreover makes clear that Plato makes the distinction in the first place in order to warn those who mistakenly call Being that which is actually Becoming (Plot. Enn. VI.2.1, esp. 21-28).

33 In Eucl. $32.21 \mathrm{ff}$. Here Proclus mentions the Timaeus as the prime example of a text in which the subject matter influences the degree of certainty. Cf. In Eucl. 211.23-212.1. This issue is related to the Domain Postulate of the Model, according to which 'all propositions and all concepts (or terms) of $S$ concern a specific set of objects or are about a certain domain of being $(s)$ '. This postulate poses interesting problems for physiologia. Space does not permit a treatment here, as it would require an extensive discussion of
} 
genera, i.e. Being and Becoming, allows Timaeus to determine which of these two is most appropriate to the subject matter, the universe, and hence discover the nature and causes of the universe from hypotheses and their consequences. Thus in the sense of preventing error by accurately distinguishing the main terms/concepts relevant within a science, the diakrisis is no less significant than a diairesis would have been. ${ }^{34}$

From all this we gather that Being and Becoming are introduced as the primitive concepts of physiologia (fulfilling condition 2a). This brings us to the question how these two concepts can, as was announced by Proclus, be defined.

\subsection{The definitions}

Because the method of division was traditionally related to definition, and because the sentence introducing the 'division' commences with 'what is...', ancient readers of the Timaeus assumed that Plato presents definitions of Being and Becoming. ${ }^{35}$ Since a division of the two concepts was impossible, however, and Being and Becoming are primitive concepts of physiologia, as a consequence, the possibility of giving a definition is also excluded. ${ }^{36}$ Not surprisingly, Proclus refers to commentators prior to him who criticised Plato for not following the rules of defining in presenting those definitions (In Tim.I.240.13-I.243.2). The two questions 'what is Being?' and 'what is Becoming?' are answered as follows:

Eternal Being is what is known through intellect (nous) and reasoning (logos),

and

Becoming is what is judged through belief (doxa) and sense perception (aisthêsis) (Tim. 28A1-28A4).

In these descriptions, the critics complained, no genus is supplied (as it should be in a proper definition) and what is worse, the descriptions do not clarify the nature of the definiendum, but describe it by our epistemological relation to them. ${ }^{37}$ Proclus, who responds to these Peripatetic criticisms with fierce indignation, does not simply reject

Footnote 33 continued

Neoplatonic ontological taxonomy. On genera in Neoplatonism see Lloyd (1990, pp. 76-97, cf. pp. 144145), Siorvanes (1996, pp. 67-69, 77-81). Cf. ?, pp. 129-130.

34 As was pointed out to me by an anonymous referee, at times Proclus uses diairesis and diakrisis as synonyms (e.g. Theol.Plat. IV 31 92). In the context of the prooemium, however, Proclus clearly considers diairesis a narrow technical term, and diakrisis a semantically less pregnant term.

35 Thus In Tim. I.227.13-I.227.18. Cf. In Parm. 982.12-982.13, In Eucl. 57.18-57.26, 69.9 ff where definitions are coupled with division as the methods 'with respect to first principles'. Cf. Buzzetti (1997, esp. pp. 332-336). Cf. Alcinous Didask. V 157.1-V 157.10 (ed. Whittaker). Note, however, that the definitions given in the Timaeus do not use the 'genera' of the division, but are definitions of those 'genera' instead. Cf. Steel (2004).

36 In Parm. 980.29 ff. On the related problem of metaphysics as a discursive science see O'Meara (1986).

37 In Tim. I.241.31-I.242.2, cf. In Tim. III.254.27-III.254.31, where Proclus calls a genuine definition one that 1 . conveys a character that is applicable to all the genera falling under the definition, 2 . expounds the essence of the definiendum, 3. does not include the definiendum in the definiens. 
them, e.g. by referring to the analogy of the Divided Line (Plato Rep. 509D ff.), but instead meets the critics on their own ground.

(1) He responds to the first objection by pointing out in an extensive discussion that Being is the highest genus, ${ }^{38}$ and that Plato could therefore not possibly have given a proper definition. To indicate that he is merely using the term 'definition' in a derivative sense, and that the two answers to the questions 'what is Being' and 'what is Becoming?' are (merely) similar to definitions, Proclus calls the 'what' ( $t i)$ in these questions 'akin to definition' (horikon), rather than 'belonging to definition' (horistikon), the more common expression. ${ }^{39}$ The rare term horikon is used by Aristotle to designate something that is not a standard definition, and does not reveal the essence (to ti ên einai), but is similar to a definition in that it does express the identity of two things. ${ }^{40}$ In this sense, the two cognitive descriptions from the proœmium are indeed akin to definition. They provide criteria that will allow us to identify (only) Being and (only) Becoming respectively, because the metaphysical distinction between Being and Becoming is correlated with that between the intelligible and the sensible. ${ }^{41}$ That this correlation is supposed by Proclus, and, in fact, by Plato himself, to exist between definiendum and definiens is also clear from the fact that an inverted version of the definition of Becoming is used later as argument in the first demonstration, concerning the nature of the universe (In Tim I.283.15-I.283.19; 292.19 ff; II.4.4, see Sect. 5). That demonstration will also show that for the definitions to serve as starting points of physiologia it is necessary that they be related primarily to the subjective discrimination by the knower.

Through his explanation of the definitions, Proclus manages to bring in 'definition' as another technical term after 'division', and then by way of a scholastic discussion of it dismisses the strictly technical meaning, while retaining the scientific context.

(2) Proclus renders the second point of criticism, that the definitions do not reveal the nature of the definienda, harmless by emphasising the didactic and anagogic purpose of both Timaeus' exposition, and the dialogue as a whole. The 'definitions' will be used later as axioms and hypotheses of the demonstrations, and as such they have to be known and evident to us (gnôrimous ...kai enargeis hêmin), ${ }^{42}$ in accordance

\footnotetext{
38 In Tim. I.242.5 ff. The defence relies on Being as including all substance (ousia), potentialities and actualities. Since substance is 'most generic', there can be no genus above Being, which includes substance. Proclus seems to follow Porphyry (Isag. 4, 1.5.1-1.5.2) and Aristotle (Met. E.1), rather than Plotinus, for whom ousia is not a genus as it is not predicated synonymously (Enn. VI.1.3), and to on is one of the five so-called highest kinds (VI.2.8.44-VI.2.8.45, cf. Plato Soph. 254E ff.), although the other four are its constituent actualities, de Haas (2001, pp. 514-515) and Chiaradonna (2002, pp. 80-81 and Ch. 3, 227 ff.). Proclus' focus on Being (as in the case of the 'division') is due to the fact that his discussion is part of a more general defence of Plato's theory of Forms.

39 In Tim. I.227.13, cf. 309.9-309.13: Plato has "secured eternal Being through the definitory explanation".

40 Top. I.5, $101 \mathrm{~b} 37 \mathrm{ff}$. Proclus uses the term horikon in a loose sense, as Aristotle's main point is that a single word (onoma) cannot be a definition, as a definition should be a proposition (logos). For the proper use of the term, see Hermias, who says that 'soul' can be defined by a 'horikon onoma', and shows that it is in fact an abbreviation of a proposition (In Phaedo $120.6 \mathrm{ff}$ ).

41 Cf. Taylor (1928, p. 61) and Zeyl (2000, p. xxviii).

42 I.242.16-I.242.19. Cf. In Tim. I.345.6 ff, II.27.1 ff. Cf. In Tim. I.226.22 ff, the first mention of the use of hypotheses and demonstrations, but in the context of the 'division'; I.229.1 ff, on philosophy of nature being a hypothetical science; or $235.32 \mathrm{ff}$, on the definitions as first starting points.
} 
with condition 7 of the Model, which states that all propositions of a science $S$ should be adequately known (de Jong and Betti 2008). Proclus' formulation harks back to Aristotle's distinction between 'what is prior and better known to us (gnôrimôteron hêmin)' and 'what is prior and better known by nature', a distinction made in the context of the requirements of the starting points of demonstrations, ${ }^{43}$ and to the very first lines of the Posterior analytics: "All teaching and all intellectual learning develop from pre-existing knowledge" (71a1-71a2).

Setting out the starting points, through which "Timaeus wants to make Being and Becoming familiar", ${ }^{44}$ is a preparatory phase before the actual unfolding of science. It is thus only reasonable that Plato presents the peculiar nature of Being and Becoming by describing the epistemic access we have of them, which will subsequently result in anamnêsis, our awakening to a clearer grasp of their nature (In Tim. I.242.26I.242.27, cf. In Tim. I.242.19-I.242.21). We now face the question, however, whether the primary concepts of physiologia can be adequately known.

\section{The foundation of philosophy of nature}

A necessary consequence of the definition of Becoming and the determination of the essence of the universe as Becoming, is that the universe is accessible to perception only, and that Timaeus' account is a description of belief based on perception. Contrary to Cornford's (1937, pp. 24, 29) suggestion, however, this conclusion is not drawn by Plato. ${ }^{45}$ More importantly for our concern, Proclus, who interprets the Timaeus as a scientific treatise, i.e. as epistêmê, has to reconcile that scientific status with the fact that due to belonging to Becoming rather than Being, the universe cannot be the subject of epistêmê.

Although obtaining such a reconciliation might seem an impossible task, ensuring scientific knowability of Becoming and giving physiologia a foundation that is both empirical and rational does not cause Proclus any trouble. We find his solution in an elegant analysis of what he calls 'the first demonstration'. That analysis, containing two at first sight rather puzzling remarks, makes a highly ingenious use of the concept of geometrical conversion, the faculty of judgment (doxa), ${ }^{46}$ and the fundamental continuity that characterises Neoplatonic reality and knowledge.

\footnotetext{
43 APo I.2, 71 b33 ff, Phys. I 1, 184a16 ff, etc. See Barnes (1994, pp. 96-97) and Mignucci (1975, pp. 30-31) for more reff.

44 In Tim. I.242.21-I.242.24. I take this to mean that they have cognitive priority prior to the positing, rather than due to the positing. In the latter case the necessity of prior positing would have no argumentative force in the defence of the content of the definitions, which is the issue at hand. The audience needs to know already that it has the different cognitive capacities and respective objects (although their names, 'Being' and 'Becoming', may be stipulated).

45 The 'likely story' is based on the ontological, not the epistemological, status of the universe. On this paradox of the Timaeus see Martijn (2008, $130 \mathrm{ff})$.

46 On the translation see below and footnote 67.
} 


\subsection{Geometrical conversion}

After the exposition of the basic concepts and propositions of philosophy of nature the first step in the so-called 'emanation', i.e. the demonstrations, is determining the essence (eidos) of the universe. More precisely, it is the inclusion of the universe in Becoming:

[The universe] has come to be: for it is visible and tangible and corporeal, and all such things are perceptible. And everything perceptible, that is, everything that is apprehended by doxa with the use of sense perception, is Becoming and generated. (Tim. 28B7-28C2)

According to Proclus this is a syllogism based on a so-called conversion of the definition of Becoming, which read "Becoming is what is judged through doxa and perception" (Tim. 28A2-28A4), and such a conversion is typical for geometry:

So it is shown demonstratively that the cosmos has become from the definition, according to the conversion (epistrophê) of the definition: for geometers also use such proofs. (In Tim. I.283.15-I.283.18)

Conversion, as a method used in geometry, is the creation of a new theorem B by exchanging the so-called hypothesis (the if-clause) of a theorem A with its conclusion, or by changing the relation of predication: if a property is predicated of a genus, in the converse theorem the genus is predicated of the property. ${ }^{47}$ In the Timaeus the definition 'everything Becoming is perceptible and opinable' is comparable to a so-called leading theorem, in which the definiendum Becoming is the genus and the definiens 'perceptible and opinable' the property. "Everything that is apprehended by doxa with the use of sense perception is Becoming and generated" (Tim. 27C1-27C2), is like a so-called converse theorem, as the genus there is predicated of the property.

The reference to geometrical practice above is intended as a justification of the use of conversion (cf. the conjunction 'for'), but it may not seem the most appropriate justification in the context, as geometrical conversion pertains to theorems, not definitions. Why doesn't Proclus refer to the Stoic conversion of definitions (also called antistrophê, SV.II.226), or to Aristotelian logical conversion? ${ }^{48}$ According to Antipater (Stoic scholarch at Athens in the second century BC), a definition should be an identity statement, and hence convertible. We can safely assume that this requirement is implicit in Proclus' discussion of the definition of Becoming, as an identity statement is also what Proclus is assuming here. If the definition were not an identity

\footnotetext{
47 Proclus refers to Euclid El. prop. 5 and its converse 6: "every isosceles has the angles at the base equal" and "if a triangle has the angles at the base equal, then it also has the sides subtending to the base equal and is isosceles" (the switch from categorical to hypothetical is irrelevant to his point). Festugière rightly remarks that Proclus does not speak of conversion of definitions in the In Eucl., but what Proclus has in mind here is the so-called conversion (antistrophê) of theorems (In Eucl. $251.23 \mathrm{ff}$, cf. Heath 1956, pp. 256-257). The use of the far more common, but inappropriate epistrophê instead of antistrophê can be explained as a slip either on Proclus' side or of a scribe's. In the second discussion of the converted definition of Becoming Proclus does use the verb antistrephein (In Tim. II.4.4 ff, ad Tim. 31B).

48 Stoic conversion is a topic in logical theory of the Aristotelian commentators, starting with Alex. Aphr. (e.g. In Metaph. 531, In Top. 241 etc.).
} 
statement, the conversion would be invalid. Proclus is not too forthcoming, however, in acknowledging Stoic influences. Moreover, a disadvantage of Stoic conversion is that it concerns equivalence relations between definiendum and definiens, but not the actual procedure of swapping them in reasoning, which is what Proclus needs.

That he does not use Aristotelian syllogistic conversion, which is a procedure, is because such a logical conversion is too weak for Proclus' purposes: in the proœmium, Plato assumes equivalence and converts a universal affirmative proposition into a universal affirmative proposition. In logical conversion, however, the converse is never a universal affirmative proposition. Therefore we need strong, i.e. geometrical conversion. 49

Proclus understood very well that the success of Plato's reasoning in the proœmium depends to a large extent on the convertibility of some of the starting points, ${ }^{50}$ and he uses his paradigm of the geometrical method to summon a context in which such convertibility is common.

\subsection{Doxa as middle term: the first puzzle}

Proclus labels Plato's procedure admirable and scientific (epistemonikôs), because, through the conversion, he gives the definition the function of a middle term, 'as one should do in demonstrations':

For in the hypotheses he defined the generated as 'judgeable' (doxaston), but for the demonstration of the [universe's] being generated he assumed the converse (i.e. 'the judgeable is generated', MM), so that he made a middle term of the definiens. (In Tim. I.292.22 ff)

The definiens of the original definition, i.e. doxaston, is a middle term in the syllogism "all that is judgeable is generated; the world is judgeable; therefore the world is generated" (cf. In Tim. I.296.20-I.296.21). ${ }^{51}$ Thus from a purely formal point of view one could say that the term doxaston allows for the conclusion to be drawn. But Proclus does not credit only the formal role of the definiens in arriving at the knowledge that the world is generated. In his analysis of the converted definition Proclus consistently leaves out the second term of the definiens, aisthêton. This exclusion of perception is not due to sloppiness, but is a deliberate choice. Proclus continues his analysis as follows:

Because the faculty of judgment (doxa) possesses the rational principles (logoi) of things that are generated, it obtains the position of the cause with respect to them. That is why, I think, Plato is not satisfied with 'being perceptible' in order to designate the generated, but adds that it is also 'judgeable' (doxaston), since perception knows the activities of the objects of perception because it is

\footnotetext{
49 On fallacious conversion, in which equivalence is wrongly presupposed, see In Eucl. $253.16 \mathrm{ff}$.

50 Cf. the criticism of Ebert (1991, pp. 46-47, 49) and the reaction of Runia (2000, pp. 107-109).

51 Taking a definition as middle term in a demonstrative syllogism is 'entirely necessary', as Proclus says (In Tim. I.292.24). On definitions as middle terms in explanatory syllogisms see Arist. APo II $1799 \mathrm{a} 21$ with Barnes (1994, p. 255).
} 
affected by them, but the faculty of judgment also knows their essences, because it possesses their logoi; so in order to reveal the proper generated essence of the objects of sense perception, he built the argument from the [term] doxaston. (In Tim. I.292.26-I.293.5)

In this passage the awkward phrase "it obtains the position of the cause with respect to them" is especially puzzling. Festugière (1966-1968, Vol. II, 143 n. 3) takes it to be a repetition of the earlier point, that the doxaston becomes the middle term, and in that sense the cause of the first demonstration, and sees doxa here as a slip for doxaston. ${ }^{52}$ But there is more to it than that. What we have here is no mere repetition of the formal role of the term doxaston, but a statement regarding the epistemological role of the faculty of doxa in the process of obtaining scientific knowledge of the perceptible world. Proclus is drawing a parallel between the hierarchy of forms of cognition and the ontological hierarchy. When he says that "doxa ...obtains the position of the cause with respect to the things that are generated", he means that in the cognitive hierarchy, doxa is the faculty that is on a parallel level to that of the proximate cause of everything generated, i.e. Nature, ${ }^{53}$ in the ontological hierarchy:

For even as Nature possesses the power of creation of things of sense by having reason-principles within it, and thus moulds and holds together the objects of sense ...so also that which possesses the power of knowing them on the general level, ${ }^{54}$ by possessing beforehand the appropriate reason-principles contemplates their common properties. (In Parm 893.11-893.17, transl. Morrow and Dillon)

In the same way as Nature possesses (creative) rational principles of the objects of sense that it generates, the faculty of judgment has a prior conception of the principles of those generated objects, but in a cognitive sense. ${ }^{55}$

It may be clear at this point that this Neoplatonic concept of doxa is a considerable stretch from Plato's view of it. A closer look is in order.

\subsection{Doxa and perception}

In the Platonic use the word for belief (doxa) traditionally has a negative ring, associated as it is with error, relativity, and non-existence. Proclus' concept of doxa, however, which is better translated '(faculty of) judgment', is more optimistic and focuses on its role in acquiring access to knowledge of the Forms. ${ }^{56}$

\footnotetext{
52 On middle term as cause in a syllogism, see Arist. APo I.2.71b22. See also Leunissen (2007).

53 Note that Nature is an ontological level distinct from the natural world, Martijn (2008, Ch. II).

54 Cf. Plato Theaet. 185-187.

55 Lautner (2002, pp. 262-263). Note that these principles are not derived from sense data (e.g. by abstraction). On this topic see Helmig (2008).

56 Lautner (2002, $258 \mathrm{ff})$. I think this is due to the fact that Proclus' concept of doxa owes a lot to the rather positive role doxa plays in the definition of knowledge as justified true belief given in the Theaetetus. The traditional translation of doxa is 'belief', and that translation should, I think, be maintained in the context of Plato's philosophy. In a Proclian context, however, 'belief' has too subjective a ring. The root of doxa (dok-)
} 
For a Neoplatonist, all knowledge is ultimately innate, based on the soul's viewing of the Forms before incarnation. The knowledge resulting from this viewing takes the shape of logoi, rational principles, in the soul, which are dormant until they are awoken by some stimulus. In first instance, that stimulus comes from outside the soul, and reminiscence is triggered by the perception of logoi, or rational structures, in the material world that are similar to the logoi inherent in the soul.

Doxa, the lowest rational capacity of the soul, which touches upon the summit of the irrational ones (In Tim. I.248.8-I.248.10, cf. III.286.30), is the faculty in which the two meet. It possesses innate rational principles (logoi) and is thereby enabled to identify immanent universals (logoi) in sense impressions, which are projections of transcendent universals, by comparing them with its own logoi ${ }^{57}$ and thus knows the essence (ousia, In Tim. I.248.11-I.248.13, I.251.28) of the objects of sense perception. ${ }^{58}$ This should not be understood in the sense that doxa "entitle[s] us to say that the apple on the desk is the one I left in the basket yesterday" (Lautner 2002, p. 258), i.e. that doxa is that which informs us merely regarding unity and identity through time. In that case we would still not know that the object in question is an apple. On the other hand, doxa is incapable of knowing the true nature of the individual as this would involve giving a definition, knowledge of the 'why': there is no such knowledge of individuals, and even if there were, doxa has no knowledge of causes (cf. Lautner 2002, pp. 258-260). Somehow, doxa is able to subsume an individual under a universal, without really knowing the universal, as that is the territory of scientific knowledge (epistêmê). ${ }^{59}$

So what exactly is the role of this concept of doxa in the first demonstration? If the definition of Becoming consisted only in 'the generated is perceptible', or more precisely, if Becoming were accessible only to sense perception, then we would not have been able to actually use the definition in any demonstrations, as we could not have had any rational cognition of the perceptible, and would have merely experienced it. It is the added accessibility to doxa (the fact that Becoming is doxaston) that provides us with the possibility of correctly judging the sensory data: everything generated can

\footnotetext{
Footnote 56 continued
}

is indeed related to subjective experience of 'being appeared to', and doxa stands both for the resulting conviction and for the faculty of the soul capable of developing such a conviction. But for Proclus doxa stands primarily for a faculty of the soul that compares and matches sense impressions with innate logoi (see below). Although 'faculty of judgment' has its own disadvantages as translation, as it suggests a Kantian Urteilskraft, it is preferable to 'belief' and 'opinion' in expressing an aspect of critique as opposed to mere conviction.

57 These logoi are not derived (e.g. by abstraction) from sense data. Cf. In Alc. 250.5-250.18. In fact the process primarily involves three logoi, namely the universal present in the sense perceptible, the logos in the soul, and the so-called 'later-born concept', an image resulting from both, that originates in doxa as a result of recollection triggered by perception. Cf. In Parm. IV $892.41 \mathrm{ff}$ and 894.19-894.23 with Steel (1997). For an extensive treatment of the 'later-born concept' see Helmig (2008).

58 In Tim. I.248.18-I.248.19; I.249.9-I.249.10; 251.5 ff; 293.3. Doxa is superior to the sensus communis, as the latter "merely distinguishes the differences between the affections of the senses, but does not know that the whole has a certain essence" (In Tim. I.249.21-I.249.22). On the sensus communis see Arist. DA III 1, De memoria 1, 450a10 ff.

59 See e.g. In Remp. I 263.15 ff. Cf. Philop. In DA 4.6-4.7: doxa "knows the universal in the sensibles, as well as the conclusions of discursive [arguments] (dianoêta)", transl. De Haas, as quoted in Sorabji (2004, p. 263). Cf. Plato Phaedr. 249B-249C on reminiscence and induction. 
be apprehended by judgment combined with sense perception, because we experience it with our senses and identify the sensory data with our faculty of judgment. Thus it is also doxa that identifies the essence of the perceptible as perceptible, and therefore as generated: "so in order to reveal the proper generated essence of the objects of sense perception, [Plato] built the argument from the [term] doxaston" (In Tim. I.293.5).

\subsection{Doxa and logos: the second puzzle}

Doxa alone, however, cannot do more than identify. It has no reasoning capacity. And this brings us to the second puzzling remark involving doxa. It concerns what seems a case of scholastic completeness. After discussing the definition of Being as 'known through intellect and reasoning', and of Becoming as 'grasped through perception and unreasoning opinion', Proclus introduces a class of things that is known through a combination of logos (not to be confused with the abovementioned logoi) and doxa. ${ }^{60}$ Just as definitions of Being and of Becoming were given by describing our cognitive access to them, it is possible to give a definition of the 'intermediate' (to meson) between pure eternal Being and pure Becoming, from the point of view of cognition:

If, after setting aside that which is always Being only and that which is generated only, you should wish to define what is intermediate as well, i.e. what is in a certain sense being and in a certain sense generated, by removing intellect from the one of the two definitions and sense-perception from the other, you will produce the definition of the intermediate. This, in fact, is what is knowable by reason and judgment. (In Tim. I.257.14-I.257.19, transl. Runia, slightly modified)

We obtain cognition of the intermediate, or intermediate cognition, by coupling the lower faculty of cognition associated with the higher realm of Being to the higher faculty associated with the lower realm of Becoming. That is, the intermediate realm is known or knowable by coupling logos to doxa.

On the face of it, this description is a scholastic filling out of the gap between two extremes, in which case it is trivial. I propose, however, that Proclus introduces an actual new level of cognition here, and one that is crucial to the scientific status of physiologia. Two questions need to be addressed in order to bring out its significance. First of all, what is the intermediate realm to which we have cognitive access through logos and doxa? And secondly and more importantly, what is the epistemological function of the combination of these two cognitive capacities, logos and doxa?

This is not the place to go into these questions in detail, so I will summarise my answers to them. ${ }^{61}$ The intermediate realm is that of those things that are either both Being and Becoming, or both Becoming and Being (there is a difference for Proclus), which means that they are generated in some respect, and eternal in another. To this

\footnotetext{
60 In Tim. I.251.17-I.251.18, cf. Lautner (2002, p. 260).

61 For a more detailed answer see Martijn (2008, Ch. III).
} 
realm belong Time, Soul, and Nature (In Tim. I.256.30 ff), which also constitute some of the main topics of Proclus' physiologia. ${ }^{62}$

The next question, then, is which form of cognition it is that combines the faculties of reasoning and judgment, and which function it has. Of course, the description logô $i$ kai doxêi gnôston ('knowable by reason and judgment') recalls a well known definition of knowledge, presented by Theaetetus (and rejected by Socrates as circular): "I had forgotten a definition I have once heard someone give, but now it's coming back to me: he said that a true judgment accompanied by an account constitutes knowledge" (tên meta logou alêthê doxan epistêmên einai, Theaet. 201C8ff). This definition may well have been Proclus' inspiration, ${ }^{63}$ but I propose moreover that our commentator takes the procedure applied in the Timaeus, and especially in the proœmium, to be an instance of just such a combined application of doxa and logos. Doxa, which primarily establishes the essence of the universe, but in general judges the data of sense perception on the basis of her innate universal logoi, presents its judgments to discursive reasoning $(\log o s)$. Reasoning in turn uses these judgments in its demonstrations, primarily in order to unveil the 'why', the causes of the universe. The scientific conclusion regarding the essence of the world depends on the (true) judgment, based on innate knowledge, that the world is perceptible, but the discursive rational method inspired on the method of geometry develops it into syllogistic reasoning, and hence scientific knowledge. Thus we have a cast-iron guarantee both of the knowability of Becoming, and of the universality of the propositions of physiologia — which thereby fulfils conditions 5 and 7 of the Model.

\section{Conclusion}

The upshot of this paper is twofold. First of all, by the case study of physiologia we have illustrated Proclus' idiosyncratic conception of science, which can be mapped onto the Classical Model of Science, but is adapted to Neoplatonic metaphysics and epistemology. And secondly, it has been shown how Proclus obtains the status of scientific knowledge for physiologia through the use of the Model. In particular, he structures the presentation of the basic concepts in a way that allows him to connect rational and empirical physiologia. For this purpose, he creates a parallel between the middle term of a syllogism and the intermediary role of the faculty of judgment. As a result, physiologia starts from universal, necessary (in the ordo essendi and cognoscendi), and known concepts and propositions.

Acknowledgements Work on this paper was funded by NWO, PhD-project 350-20-005. It incorporates material from the third chapter of my dissertation Philosophy of nature and its methods in Proclus' Commentary on Plato's Timaeus. I would like to thank Frans de Haas and an anonymous referee for commenting on earlier versions of this paper.

\footnotetext{
62 After the introductory first book of the In Tim., book II is devoted to the divine causes of the universe, book III to body and soul of the universe, book IV is a treatment of time, and book V deals with the planets and the creation of body and soul of human beings.

63 Proclus would not be held back by the fact that the logos in the Theaetetus is not the faculty of discursive reasoning, but rather a rational account by way of justification of a true judgment.
} 
Open Access This article is distributed under the terms of the Creative Commons Attribution Noncommercial License which permits any noncommercial use, distribution, and reproduction in any medium, provided the original author(s) and source are credited.

\section{References}

Aristotle. Analytica posteriora. W. D. Ross (Ed.) (1986), Oxford: Clarendon Press. J. Barnes (Trans.). (1994). Posterior analytics. Oxford: Clarendon Press.

Beierwaltes, W. (1979). Proklos. Grundzüge seiner Metaphysik. Frankfurt am Main: Klostermann.

Buzzetti, D. (1997). On Proclus' comparison of Aristotelian and Parmenidean logic. In J. J. Cleary (Ed.), The perennial tradition of Neoplatonism (pp. 331-346). Leuven: Leuven University Press.

Chiaradonna, R. (2002). Sostanza, movimento, analogia. Plotino critico di Aristotele. Napoli: Bibliopolis.

Cornford, F. M. (1937). Plato's cosmology. The Timaeus of Plato translated with a running commentary. London: Routledge \& Kegan Paul.

de Haas, F. A. J. (2001). Did Plotinus and Porphyry disagree on Aristotle's Categories? Phronesis, 44, 492-526.

de Jong, W. R., \& Betti, A. (2008). The Classical Model of Science: A millennia-old model of scientific rationality. Synthese. doi:10.1007/s11229-008-9417-4.

Dillon, J. (1993). Alcinous. The handbook of Platonism (Trans., Intro. \& Commentary). Oxford: Clarendon Press.

Ebert, T. (1991). Von der Weltursache zum Weltbaumeister: Bemerkungen zu einem Argumentationsfehler im platonischen Timaios. Antike und Abendland, 37, 43-54.

Festugière, A.-J. (1963). Modes de composition des commentaires de Proclus. Museum Helveticum, 20, 77-100. Reprinted in Études de Philosophie Grecque, 26 (1971), 551-574.

Festugière, A.-J. (1966-1968). Proclus commentaire sur le Timée. Paris: Vrin.

Gerson, L. P. (2005). Aristotle and other Platonists. Ithaca: Cornell University Press.

Hathaway, R. (1982). The anatomy of a Neoplatonist metaphysical proof. In R. B. Harris (Ed.), The structure of being. A Neoplatonic approach (pp. 122-136). New York: State University of New York Press.

Heath, T. L. (1956). Euclid. The thirteen books of the Elements. Vol. 1. (Trans., Intro. \& Commentary). New York: Dover.

Helmig, C. (2008). Proclus' criticism of Aristotle's theory of concept formation in Analytica Posteriora II 19. In F. A. J. de Haas \& M. E. M. P. J. Leunissen (Eds.), Interpreting Aristotle's Posterior analytics. Leiden: Brill (in press).

Lautner, P. (2002). The distinction between phantasia and doxa in Proclus' In Timaeum. Classical Quarterly, $52,257-269$.

Lernould, A. (1987). La dialectique comme science première chez Proclus. Revue des Sciences Philosophiques et Théologiques, 71, 509-536.

Lernould, A. (2001). Physique et théologie. Lecture du Timée de Platon par Proclus. Villeneuve d'Ascq: Septentrion.

Leunissen, M. E. M. P. J. (2007). The structure of teleological explanations in Aristotle: Theory and practice. Oxford Studies in Ancient Philosophy, 33, 145-178.

Lloyd, A. C. (1990). The anatomy of Neoplatonism. Oxford: Clarendon Press.

Lohr, C. H. (1986). The pseudo-Aristotelian Liber de causis and Latin theories of science in the twelfth and thirteenth centuries. In J. Kraye, W. F. Ryan, \& C. B. Schmitt (Eds.), Pseudo-Aristotle and the Middle Ages (pp. 53-62). London: Warburg Institute.

Longo, A. (2005). Siriano e i principi della scienza. Napoli: Bibliopolis.

Longo, A. (2006). La présence d'Aristote et son assimilation originale de la part de Plotin dans l' 'Enneade' VI.5 [23]. Etudes Platoniciennes, 3, 155-173.

Lowry, J. M. P. (1980). The logical principles of Proclus' Stoicheiosis theologike as systematic ground of the cosmos. Amsterdam: Rodopi.

Martijn, M. (2006). The eikôs mythos in Proclus' Commentary on the Timaeus. In H. Tarrant \& D. Baltzly (Eds.), Reading Plato in antiquity (pp. 151-167). London: Duckworth.

Martijn, M. (2008). Proclus on nature. Philosophy of nature and its methods in Proclus' Commentary on Plato's Timaeus. Dissertation, Leiden University.

Mignucci, M. (1975). L'argomentazione dimostrativa in Aristotele. Commento agli Analitici secondi. Padova: Antenore. 
Mourelatos, A. P. (1991). Plato's science: His view and ours of his. In A. C. Bowen (Ed.), Science and philosophy in classical Greece (pp. 11-30). New York: Garland.

Nikulin, D. (2003). Physica more geometrico demonstrata: Natural philosophy in Proclus and Aristotle. Proceedings of the Boston Area Colloquium in Ancient Philosophy, 18, 183-221.

O’Meara, D. J. (1986). Le problème de la métaphysique dans l'antiquité tardive. Freiburger Zeitschrift für Philosophie und Theologie, 33, 3-22.

O’Meara, D. J. (1989). Pythagoras revived. Oxford: Clarendon Press.

O'Meara, D. J. (2000). La science métaphysique (ou théologie) de Proclus comme exercise spirituel. In A. Segonds \& C. Steel (Eds.), Proclus et la théologie Platonicienne (pp. 279-290). Leuven: Leuven University Press.

Plato. Platonis Opera I-V. J. Burnet (Ed.) (1900-1907). Oxford: Oxford Classical Texts.

Porphyrius, Isagoge sive quinque voces. Busse, A. (Ed.) (1887). Commentaria in Aristotelem Graeca. iv 1. Berlin: Reimer. Barnes, J. (Trans.) (2003). Porphyry. Introduction. Oxford: Oxford University Press.

Proclus. In Platonis Timaeum Commentaria. E. Diehl (Ed.) (1903-1906). Leipzig: Teubner.

Proclus. In Platonis Cratylum Commentaria. G. Pasquali (Ed.) (1908). Leipzig: Teubner.

Runia, D. T. (1997). The literary and philosophical status of Timaeus' proœmium. In T. Calvo \& L. Brisson (Eds.), Interpreting the Timaeus-Critias. Proceedings of the IV Symposium Platonicum selected papers (pp. 101-118). Sankt Augustin: Academia Verlag.

Runia, D. T. (2000). Timaeus, logician and philosopher of nature. In J. Spruyt \& M. Kardaun (Eds.), The winged chariot. Collected essays on Plato and Platonism in honour of L. M. de Rijk (pp. 105-118). Leiden: Brill.

Scholz, H. (1930/1975). Die Axiomatik der Alten. In J. Barnes, M. Schofield, \& R. Sorabji (Eds.). (1975). Articles on Aristotle 1: Science (pp. 50-64). London: Duckworth.

Siorvanes, L. (1996). Proclus. Neo-Platonic philosophy and science. New Haven: Yale University Press.

Sorabji, R. (2004). The philosophy of the commentators 200-600 AD. A sourcebook. Volume 3: Logic \& metaphysics. London: Duckworth.

Steel, C. (1997). Breathing thought: Proclus on the innate knowledge of the soul. In J. J. Cleary (Ed.), The perennial tradition of Neoplatonism (pp. 293-309). Leuven: Leuven University Press.

Steel, C.(2004). Definitions and ideas. Proceedings of the Boston Area Colloquium in Ancient Philosophy, 19, 103-121.

Taylor, A. E. (1928). A commentary on Plato's Timaeus. Oxford: Clarendon Press.

Vlastos, G. (1975). Plato's universe. Oxford: Clarendon Press.

Whittaker, J. (1990). Alcinoos. Enseignement des doctrines de Platon. Paris: Les Belles Lettres.

Zeyl, D. J. (2000). Plato. Timaeus. Indianapolis: Hackett. 